\title{
Flow descriptors for parametric hydrographs accounting for afforestation of the catchment
}

\section{Beata BAZIAK (D), Wiesław GADEK iD, Marek BODZIONY (D)}

Cracow University of Technology, Faculty of Environmental Engineering, Warszawska 24, 31-155 Kraków, Poland, e-mail: beata.baziak@iigw.pk.edu.pl,wieslaw.gadek@iigw.pk.edu.pl, marek.bodziony@iigw.pk.edu.pl

\section{Tamara TOKARCZYK}

Institute of Meteorology and Water Management - National Research Institute; Podleśna 61, 01-673 Warszawa, Poland

\section{DOI: $10.26491 / \mathrm{mhwm} / 111033$}

\footnotetext{
ABSTRACT. Parametric flow hydrographs are used for design and management purposes in such fields as water management and aquatic engineering. They describe a theoretical hydrograph based on such parameters as maximum flow, time to peak, and surge duration. They are used to forecast flood risk and to evaluate the impact of land use on the run-off hydrograph. In Western Europe for many years methods have been used in which parametric hydrographs are determined based on physical catchment descriptors (PCDs), which are divided into three groups describing the physical features of a catchment. These descriptors are used to derive formulae enabling the determination of parametric flow hydrographs for any computational cross-section. In this work, such formulae are derived for the catchment of the Raba River, using the principles of design hydrology applied in Western European countries. The parametric hydrograph is described using Baptista's gamma density function. The input hydrograph was a nonparametric flow hydrograph determined by Archer's method. For nine gauging stations located in the Raba catchment, physical catchment descriptors were obtained for two 30-year periods: 1961-1990 and 19832012. Based on the nonparametric flow hydrograph and the PCDs, two groups of formulae were derived to describe the parametric hydrograph. Analysis of agreement between the computed parametric flow hydrographs and the input hydrograph indicated a high quality of fit. It should be noted that the formulae and analysis presented here refer only to the Raba catchment. However, the results confirm the possibility of applying these methods to the determination of parametric flow hydrographs for any river cross-section.
}

KEYWORDS: hysical catchment descriptors, gamma density function, parametric flow hydrograph, Archer's method, skewness coefficient, hydrograph width 


\section{INTRODUCTION}

Parametric hydrographs are used in water and wastewater management and spatial planning, as well as in aquatic and hydraulic engineering, in cases where variation of the flow in a watercourse plays an important role in the design or computational process (O'Connor et al. 2014). Flow hydrographs describe the theoretical course of a surge, using such parameters as maximum flow, time to peak, and surge duration. Hydrographs of this type are also used in assessing the impact of urbanised areas on flood risk, or the impact of afforestation in ameliorating the effects of floods. The method is used in relation to both existing land use and planned developments in river catchment areas. Hydrographs are also used in planning the capacity of storage reservoirs, one of the purposes of which is to reduce the effects of floods and water shortages at times of drought (Mioduszewski 2012, 2014)

The history of the use of flow hydrographs goes back to the 1930s. It is generally considered that the theory of isochrones developed by Dubelir, Boldakov, and Čerkašin initiated the development of hydrographs of this type for practical engineering purposes. That theory is based on a generic equation of a flood crest. Until the mid-1960s this equation was solved with the use of simplifications, which produced hydrographs of trapezoidal or triangular shape (Strupczewski 1964; Strupczewski et al. 2013).

The first analytical description of a hydrograph was provided by the functions proposed by Reitz and Kreps (Reitz, Kreps 1945; Gądek, Środula 2014). In that method, the rising limb of the hydrograph of the Reitz-Kreps equation is a squared sine function, and the recession limb is an exponential function. The method is still in use today.

An important date is 1957, when Nash's cascade model was introduced for what is called the Instantaneous Unit Hydrograph (IUH) (Nash 1957). In many countries, the gamma density function used by Nash in that model has become the basis for the description of an analytical hydrograph, known as a parametric design hydrograph.

In this work we propose the introduction in Poland of new principles for the construction of empirical formulae, as used in Western European countries, among others, for design hydrology. These formulae enable the determination of parametric flow hydrographs based on:

- the hydrograph width (hours) at 50\% and $75 \%$ of peak flow (W50 and W75) and the hydrograph skewness coefficient $s$;
- the shape parameter of the hydrograph $n$ and the time to peak $t_{p}$ of the gamma distribution function.

An innovative feature of this method is the ability to determine parametric flow hydrographs for any river cross-section based on equations constructed using the above parameters.

The proposed method is analysed in the catchment of the Raba River, where nine gauging stations are situated. For the data from these stations, an assessment is made of the agreement between the parametric flow hydrographs and nonparametric hydrographs obtained by Archer's method.

\section{MATERIALS AND METHODS}

The proposed method of determining a parametric design hydrograph using physical catchment descriptors (PCDs) is based on design hydrology. This term, used in European countries and in the United States, denotes a form of hydrology distinct from the existing engineering hydrology in that it combines the computational methods recommended in engineering hydrology with dynamic (process) hydrology, and makes use of data acquisition, data processing, and presentation of results in a GIS. The technique has been developed for such purposes as the management of water resources, the designation of zones endangered by or at risk of flood, assessment of the impact of urbanised areas on flood risk and drought, and determination of the effects of climate change on water resources.

A principle of design hydrology is the use of universal computational methods over large areas, which means that at every level of management it is possible to perform various types of hydrological analyses, in view of the simplicity of using system and the lack of ambiguity in the computed hydrological characteristics.

The parameters used in the computational formulae are called physical catchment descriptors (PCDs). These can be divided into three groups:

- fixed: related to the topography, orography, and hydrography of the catchment, including, e.g., the area of the catchment, the density of the river network, gradient of the river, etc.;

- variable: representing the spatial development of the basin, e.g., forest cover, urbanisation, length of watercourses subjected to anthropogenic pressure, etc.;

- process-related: e.g., moisture content of the catchment, surface retention, channel and lake dampening, urbanisation pressure on the outflow, etc.

In Poland, the methods employed to date use hypothetical waves, determined based on what are known as typical hydrographs, for example, with the highest recorded flow or the highest values of, say, six or eight surges in a selected period. These methods include Reitz and Kreps (1945), Warsaw University of Technology (Gądek et al. 2016), Hydroprojekt (Gądek, Środula 2014) and Cracow (Gądek, Tokarczyk 2015; Gądek et al. 2016). They also include Strupczewski's analytic wave (Ciepielowski 1987, 2001; Strupczewski et al. 2013; Gądek et al. 2017b).

The parametric design hydrographs proposed in design hydrology can be determined in any desired river cross-sections irrespective of catchment size, thanks to a method developed by Archer. This method entails the determination of nonparametric hydrographs - that is, a median of flow hydrographs - and their use to determine flow duration descriptors with probabilities of being exceeded ranging from $95 \%$ to $5 \%$ in steps of $5 \%$. The value of the $98 \%$ flow duration descriptor is also determined (Archer et al. 2000). A nonparametric hydrograph has an independent rising limb and an independent recession limb (Fig. 1). Flows are presented in the form of percentage contribution in a range from $0 \%$ to $100 \%$, where $100 \%$ denotes the maximum value. The horizontal axis is the duration of particular values of percentage contributions together with higher values. The time is given as negative values for the rising limb of the hydrograph, and positive values for the recession limb. At time $t=0$ the maximum percentage contribution $(q=100 \%)$ occurs. For particular values of percentage contributions of flows, the time is determined in the form of a median, separately for the rising limb and for the recession limb (O'Connor, Goswami 2009; O’Connor et al. 2014; Gądek et al. 2017a, b). Such a nonparametric hydrograph ought to be determined based on a 30-year series of flow data used in the process of computing maximum flows with a given probability of being exceeded.

In the case of hypothetical waves, hydrographs were determined based on time criteria, while in the case of nonparametric Archer hydrographs, time is determined based on unified flow. 
For the description of a parametric design hydrograph the gamma density function is used, based on:

- the single shape parameter $m$ (O'Connor et al. 2014; Strupczewski 1964; Strupczewski et al. 2013);

- the single shape parameter $n$ (Baptista 1990; Baptista, Michel 1990);

- or the two shape parameters $m$ and $n$ (Strupczewski 1964; Strupczewski et al. 2013; Gądek et al. 2017b).

The basic formula for the gamma density function with two wave shape parameters has the form:

$$
\mathrm{q}_{\mathrm{t}}=\left(1+\frac{\mathrm{t}}{\mathrm{t}_{\mathrm{p}}}\right)^{\mathrm{m}} \exp \left\{\frac{\mathrm{m}}{\mathrm{n}}\left[1-\left(1+\frac{\mathrm{t}}{\mathrm{t}_{\mathrm{p}}}\right)^{\mathrm{n}}\right]\right\} \quad 100 \%
$$

where: $q_{t}$ is the percentage of peak flow at time $t[\%] ; t$ is the time to peak [h]; $t$ is the time from the beginning of the rising limb [h]; $m, n$ are unitless shape parameters.

A function proposed by Baptista is similar in form, derived based on a hydrological model of transformation in the channel of the Muskingum River:

$$
\mathrm{q}_{\mathrm{t}}=\left(1+\frac{\mathrm{t}}{\mathrm{t}_{\mathrm{p}}}\right)^{2} \exp \left\{\frac{2}{\mathrm{n}}\left[1-\left(1+\frac{\mathrm{t}}{\mathrm{t}_{\mathrm{p}}}\right)^{\mathrm{n}}\right]\right\} 100 \%
$$

As a result of our analyses, the single-parameter distribution proposed by Baptista was selected.

\subsection{STUDY AREA}

The study area was the catchment of the Raba River, which flows through three hydrological regions. The largest part of the catchment lies in the mountainous Carpathian zone. The average elevation in the catchment is approximately 500 metres above sea level; the highest point is Mount Turbacz (1,310 m a.s.l.) and the lowest is the river's confluence with the Vistula at $180 \mathrm{~m}$ a.s.l. The river may be divided into three sections:

- the upper section, in the Beskid Mountains, $60 \mathrm{~km}$ long, with average slope $0.85 \%$;

- the middle section, in the foothill region, 34 $\mathrm{km}$ long with average slope $0.23 \%$;

- the lower section, in the Sandomierz Basin, $43 \mathrm{~km}$ long with average slope $0.06 \%$.

Within the catchment there are nine gauging stations and a barrier reservoir in Dobczyce. Fig-

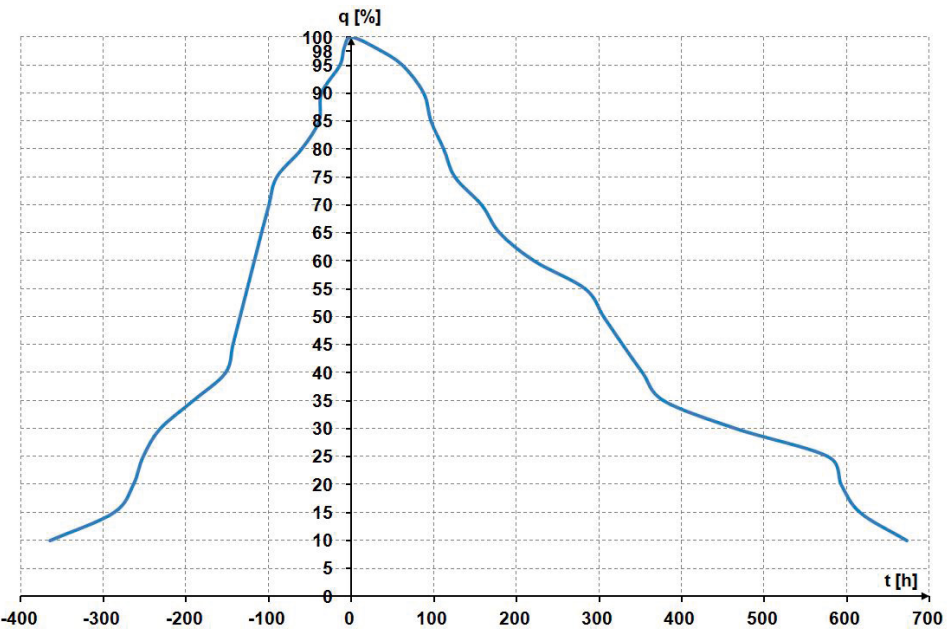

Fig. 1. Example nonparametric design hydrograph obtained by Archer's method

Table 1. Physiographic parameters of the Raba catchment according to the Polish Hydrographic Division (IMGW 1980a)

\begin{tabular}{|l|c|}
\hline Parameter & Value \\
\hline Catchment area & $1,537.1 \mathrm{~km}^{2}$ \\
\hline Main river length & $131.9 \mathrm{~km}$ \\
\hline River slope & $4.47 \mathrm{~m} / \mathrm{km}$ \\
\hline Drainage density & $2.16 \mathrm{~km} \cdot \mathrm{km}^{-2}$ \\
\hline River source elevation & $780 \mathrm{~m}$ a.s.l. \\
\hline Final confluence elevation & $190 \mathrm{~m}$ a.s.l. \\
\hline
\end{tabular}

Table 2. Land cover types of the Raba catchment according to CORINE Land Cover

\begin{tabular}{|l|c|c|}
\hline \multirow{2}{*}{ Cover types } & \multicolumn{2}{|c|}{ Area [\%] } \\
\cline { 2 - 3 } & 1990 & 2012 \\
\hline Discontinuous urban fabric & 1.62 & 5.71 \\
\hline Industrial or commercial units & 0.11 & 0.20 \\
\hline Mineral extraction sites & 0.02 & 0.06 \\
\hline Green urban areas & 0.05 & 0.02 \\
\hline Sport and leisure facilities & - & 0.05 \\
\hline Non-irrigated arable land & 30.19 & 31.91 \\
\hline Fruit trees and berry plantations & 0.53 & 1.35 \\
\hline Pastures & 2.62 & 2.74 \\
\hline Complex cultivation patterns & 15.71 & 9.17 \\
\hline Land principally occupied by agriculture, with significant areas of natural vegetation & 16.21 & 12.57 \\
\hline Broad-leaved forest & 4.37 & 4.45 \\
\hline Coniferous forest & 16.96 & 17.99 \\
\hline Mixed forest & 10.81 & 11.98 \\
\hline Transitional woodland - shrub & 0.09 & 1.05 \\
\hline Water bodies & 0.70 & 0.76 \\
\hline
\end{tabular}

ure 2 shows the subcatchments for the gauged cross-sections for which computations were performed. The Raba catchment was chosen for study because of the dominance of forests in its upper part. The distribution of forests according to the CORINE Land Cover system, from the years 1990 and 2012 (CLC1990, CLC2012'), is shown in Figure 3.

Physical catchment descriptors for the Raba catchment were determined at nine gauging stations.

\subsection{ANALYTICAL METHODOLOGY}

\subsubsection{PHYSICAL CATCHMENT} DESCRIPTORS

To construct empirical formulae enabling the determination of parametric flow hydrographs, physical catchment descriptors from the three groups were used: the fixed descriptors ADO, GSR, S1085; the variable descriptor LAS (Bayliss 1999); and the process-related descriptors GLEMOK, JEZ.

${ }^{1}$ https://land.copernicus.eu/pan-european/corine-land-cover 

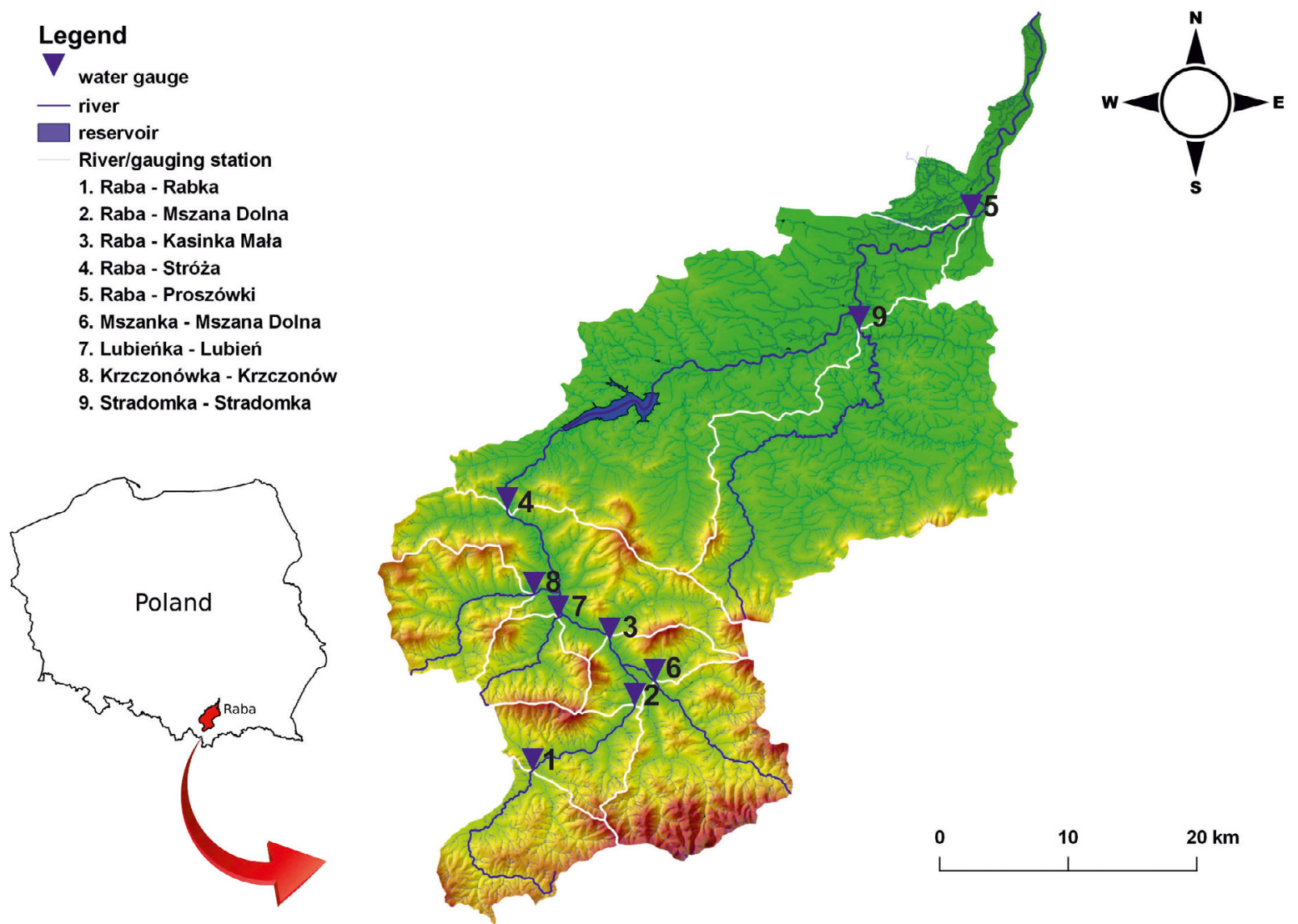

Fig. 2. Gauging stations in the Raba catchment

\section{LEGEND}

COVER TYPES

Discontinuous urban fabric

Industrial or commercial units

Mineral extraction sites

Green urban areas

Sport and leisure facilities

Non-irrigated arable land

Fruit trees and berry plantations

Pastures

Complex cultivation patterns

Land principally occupied by agriculture, with significant areas of natural vegetation

Broad-leaved forest

Coniferous forest

Mixed forest

Transitional woodland-shrub

Water bodies
0

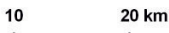

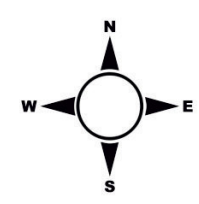

a)

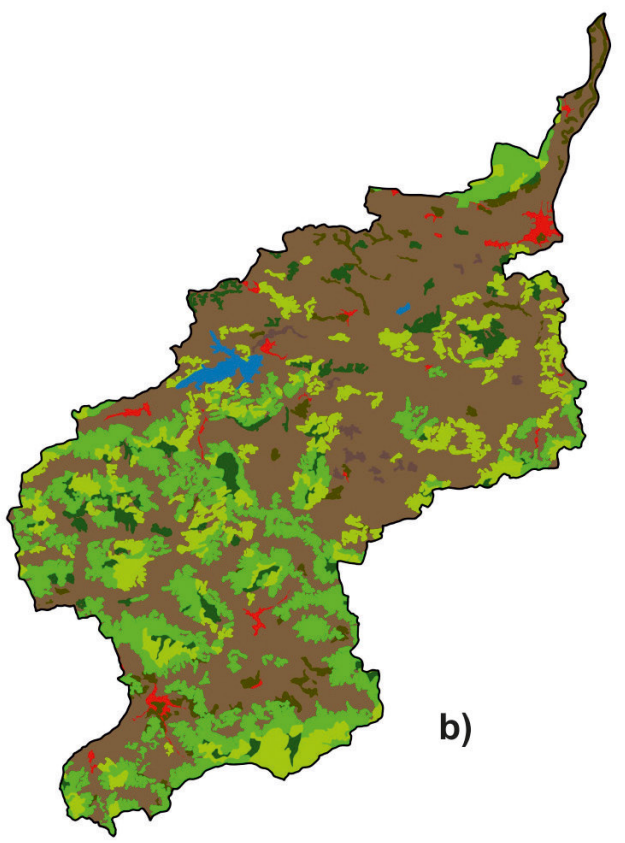

Fig. 3. Land cover of the Raba catchment according to CORINE Land Cover: a) 1990; b) 2012 
$q[\%]$

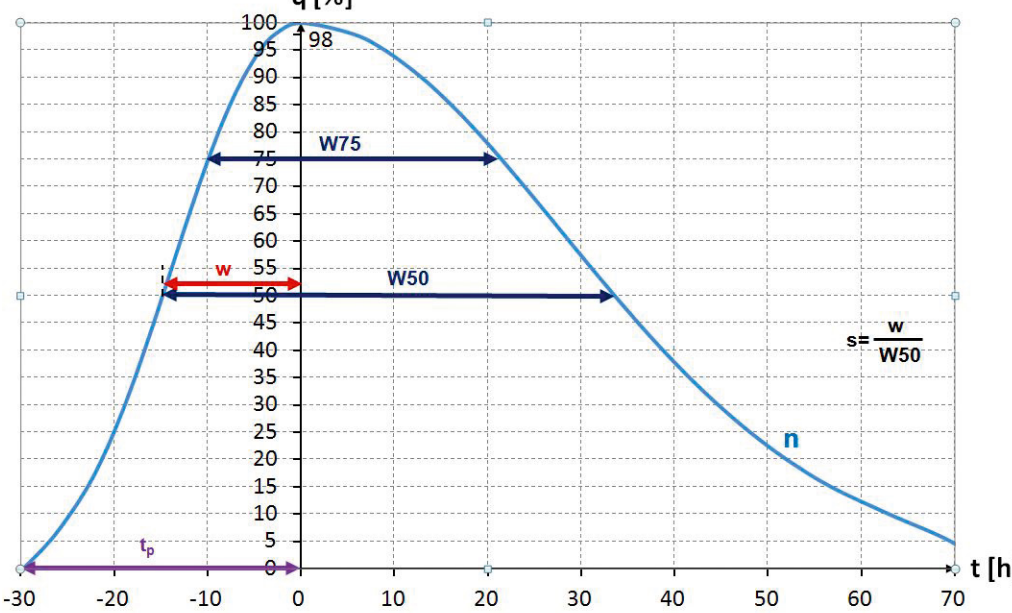

Fig. 4. Example parametric design hydrograph

The ADO descriptor represents the proportion of the area drained directly by tributaries, modelled on the ARTDRAIN descriptor (Bayliss 1999), and given by the formula:

$$
A D O=\frac{\sum A_{e l i}}{A}
$$

where: $A_{e l}$ is the area of a subcatchment (over $\left.2.5 \mathrm{~km}^{2}\right)\left[\mathrm{km}^{2}\right] ; A$ is the area of the catchment upstream from the gauging station $\left[\mathrm{km}^{2}\right]$.

The GSR descriptor represents the drainage density, and is modelled on the DRAIND descriptor (Bayliss 1999) according to the formula:

$$
G S R=\frac{\sum L_{i}}{A}
$$

where: $L$ is the length of a watercourse for which the catchment area exceeds $2.5 \mathrm{~km}^{2}$ $[\mathrm{km}] ; A$ is the catchment area upstream from the gauging station $\left[\mathrm{km}^{2}\right]$.

The S1085 descriptor, representing the slope of the main river (Bayliss 1999), is computed based on the drop in elevation of the river between the theoretical source and the theoretical computational cross-section, and the length of the river between them. The theoretical computational cross-section is located at a distance of $10 \%$ of the river length above the computational cross-section. The theoretical source is located at a distance of $85 \%$ of the river length above the computational cross-section.

$$
S 1085=\frac{W 85-W 10}{L 1085}
$$

${ }^{2}$ https://dane.gov.pl

${ }^{3}$ https://www.eea.europa.eu/data-and-maps/data/eu-dem and the soil types occurring in the catchment. Thisbalanceiscalculatedfortheperiodfrom 1Aprilto 31 October of each year - that is, for the growing season. It is assumed that on 1 April the soil is fully saturated. The boundary between wet and dry soil was determined based on the weighted average of the areas covered by particular soil types and the $\mathrm{pF}$ curves (Driessen, Konijn 1992) for each soil type. The GLEMOK descriptor was computed in 1990 for the computation period 1961-1990 and in 2012 for the period 1983-2012.

The JEZ descriptor, describing the process of flood attenuation by reservoirs and lakes, is modelled on the FARL descriptor (Bayliss 1999). It is computed from the formula:

$$
J E Z=\prod \alpha_{i}
$$

where: W85 is the elevation of the river at a cross-section located at a distance of $85 \%$ of the river length above the computational cross-section $[\mathrm{km}] ; W 10$ is the elevation of the river at a cross-section located at a distance of $10 \%$ of the river length above the computational cross-section [km]; L1085 is the length of the main river excluding sections of $10 \%$ of its length above the computational cross-section and $15 \%$ of its length from the source $[\mathrm{km}]$.

This slope is used in place of the average slope computed by the Taylor-Schwartz method (Bayliss 1999).

The LAS descriptor, representing the degree of afforestation of the catchment, modelled on the FOREST descriptor (Bayliss 1999), is computed from the formula:

$$
L A S=\frac{\sum A_{L A S i}}{A}
$$

where: $A_{L A S}$ is the area of forest according to CORINE Land Cover $\left[\mathrm{km}^{2}\right] ; A$ is the area of the catchment up to the gauging station $\left[\mathrm{km}^{2}\right]$.

The LAS descriptor was computed in 1990 for the computation period 1961-1990 and in 2012 for the computation period 1983-2012.

The GLEMOK descriptor represents the time during which the soil is wet. It is based on the PROPWET descriptor developed in the UK (Bayliss 1999; Reed 2007) and the FLATWET descriptor used in Ireland (Mills 2009; Mills et al. 2014), modified by the exclusion of the winter period. For Polish conditions, GLEMOK is determined for the 30-year series of measurement data as the net balance of supply (precipitation) and losses (terrain evaporation) for the daily data where:

$$
\begin{gathered}
\alpha=(1-\sqrt{r})^{w} \\
r=\frac{A_{J E Z}}{a} \\
w=\frac{a}{A}
\end{gathered}
$$

$A_{J E Z}$ is the area of the reservoir/lake $\left[\mathrm{km}^{2}\right]$; $a$ is the catchment area up to the cross-section closed by a dam or hydraulic structure $\left[\mathrm{km}^{2}\right]$; $A$ is the catchment area up to the gauging station $\left[\mathrm{km}^{2}\right]$.

The descriptors (PCDs) listed above were determined using digital and analogue data obtained from:

- the Polish Hydrographic Division map (mphp);

- CORINE Land Cover (CLC1990, CLC2012);

- the numerical terrain model (NMT) ${ }^{3}$;

- the Polish hydrographic division atlas (distribution of soils) (IMGW 1980a, b);

- the Polish hydrological atlas (indices of spatial distribution of precipitation and values of terrain evaporation) (IMGW 1988a, b);

- weather data, including precipitation for the years 1983-2006, from the Stróża station maintained by the Hydrology Group of the Institute of Aquatic Engineering and Water Management at Tadeusz Kościuszko University of Technology, and for the years 2007-2012 from the IMGW-PIB weather station in Dobczyce.

\subsubsection{PARAMETRIC DESIGN HYDROGRAPHS}

Based on the nonparametric flow hydrograph obtained byArcher's method, a deter- 
Table 3. Physical catchment descriptors (PCDs) for gauging stations in the Raba catchment

\begin{tabular}{|c|c|c|c|c|c|c|c|c|c|}
\hline \multirow{2}{*}{ River/gauging station } & \multirow{2}{*}{$\frac{A}{\mathrm{~km}^{2}}$} & \multirow{2}{*}{$\begin{array}{c}\text { GSR } \\
\mathrm{km} \mathrm{km}^{-2}\end{array}$} & \multirow{2}{*}{$\begin{array}{l}\mathrm{S} 1085 \\
\mathrm{~m} \mathrm{~km}^{-1}\end{array}$} & \multirow[t]{2}{*}{ ADO } & \multirow[t]{2}{*}{ JEZ } & \multicolumn{2}{|c|}{ LAS } & \multicolumn{2}{|c|}{ GLEMOK } \\
\hline & & & & & & 1990 & 2012 & 1990 & 2012 \\
\hline Raba - Rabka & 91.7 & 2.61 & 8.99 & 0.58 & 1.00 & 0.39 & 0.45 & 0.62 & 0.63 \\
\hline Raba - Mszana Dolna & 157.1 & 2.55 & 8.59 & 0.64 & 1.00 & 0.38 & 0.43 & 0.59 & 0.58 \\
\hline Raba - Kasinka Mała & 352.9 & 2.38 & 7.51 & 0.81 & 1.00 & 0.42 & 0.43 & 0.59 & 0.54 \\
\hline Raba - Stróża & 643.1 & 2.15 & 6.24 & 0.86 & 1.00 & 0.45 & 0.49 & 0.55 & 0.52 \\
\hline Raba - Proszówki & $1,470.4$ & 2.00 & 3.53 & 0.85 & 0.95 & 0.32 & 0.35 & 0.53 & 0.50 \\
\hline Mszanka - Mszana Dolna & 151.4 & 2.37 & 16.00 & 0.31 & 1.00 & 0.46 & 0.47 & 0.54 & 0.50 \\
\hline Lubieńka - Lubień & 47.8 & 2.16 & 7.73 & 0.55 & 1.00 & $0.44^{\circ}$ & 0.49 & 0.52 & 0.50 \\
\hline Krzczonówka - Krzczonów & 87.3 & 1.86 & 13.82 & 0.64 & 1.00 & 0.48 & 0.55 & 0.46 & 0.44 \\
\hline Stradomka - Stradomka & 362.5 & 1.99 & 4.67 & 0.80 & 1.00 & 0.25 & 0.26 & 0.41 & 0.39 \\
\hline
\end{tabular}

* Data not used for optimisation due to incompleteness of the (30-year) series of measurement data in the analysed period

Table 4. Hydrograph width $W 50, W 75$, and skewness coefficient s and their relative errors at gauged cross-sections

\begin{tabular}{|c|c|c|c|c|c|c|c|c|c|c|c|c|c|}
\hline \multirow{2}{*}{ No } & \multirow{2}{*}{ River/gauging station } & \multicolumn{2}{|c|}{ W50 } & \multicolumn{2}{|c|}{ W75 } & \multicolumn{2}{|c|}{$s$} & \multicolumn{2}{|c|}{$R E_{W 50}$} & \multicolumn{2}{|c|}{$R E_{W 75}$} & \multicolumn{2}{|c|}{$R E_{s}$} \\
\hline & & 1990 & 2012 & 1990 & 2012 & 1990 & 2012 & 1990 & 2012 & 1990 & 2012 & 1990 & 2012 \\
\hline 1 & Raba - Rabka & 34.9 & 32.7 & 15.8 & 14.5 & 0.4 & 0.4 & 2.6 & 8.2 & 15.2 & 0.4 & 1.8 & 11.6 \\
\hline 2 & Raba - Mszana Dolna & 35.1 & 32.5 & 9.4 & 13 & 0.5 & 0.4 & 6.4 & 1.6 & 35.3 & 0.6 & 7.8 & 9.6 \\
\hline 3 & Raba - Kasinka Mała & 36.8 & 31.6 & 16.2 & 13.7 & 0.4 & 0.5 & 7.1 & 2.1 & 14.1 & 6.2 & 1.5 & 3.3 \\
\hline 4 & Raba - Stróża & 33.9 & 33.2 & 16.2 & 14.5 & 0.4 & 0.4 & 4 & 3.3 & 5.1 & 14.2 & 4 & 2.1 \\
\hline 5 & Raba - Proszówki & & 42.6 & & 18.7 & & 0.4 & & $0.8^{\circ}$ & & $0.5^{\circ}$ & & $1.2^{\circ}$ \\
\hline 6 & Mszanka - Mszana Dolna & 31.2 & 26.8 & 13.8 & 11.5 & 0.5 & 0.5 & 3.2 & 7.3 & 1 & 10.8 & 10.2 & 2.4 \\
\hline 7 & Lubieńka - Lubień & & 33.6 & & 17.5 & & 0.4 & & 1.1 & & 2.2 & & 11.8 \\
\hline 8 & Krzczonówka - Krzczonów & 29.7 & 27.5 & 14.9 & 13.3 & 0.5 & 0.5 & 4.1 & 2.4 & 6.6 & 5.6 & 2.8 & 0.9 \\
\hline 9 & Stradomka - Stradomka & 28.4 & 26.3 & 14.4 & 13.3 & 0.5 & 0.5 & 1.9 & 1.8 & 5.6 & 3.8 & 1.9 & 0.8 \\
\hline
\end{tabular}

* the error value is affected by the JEZ descriptor, which was not considered in the optimisation due to the absence of impact of the reservoir on eight of the nine gauging stations

mination was made of the values of hydrograph width at $50 \%$ (W50) and $75 \%$ (W75) of peak flow. These descriptors were selected based on experience gained by scientists working on design hydrology in Ireland (O'Connor et al. 2014). An additional parameter describing the parametric flow hydrograph is the skewness coefficient $s$. Baptista's gamma density function requires computation of the shape parameter $n$ and the time to peak $t_{p}$ (Fig. 4).

To construct empirical formulae describing the parametric flow hydrograph, an optimisation process was used, taking as the target function the minimum deviation of the sum of squares between the given and computed values, according to the general formula:

$$
f=\sum_{i=1}^{k} \sqrt{(x-\hat{x})^{2}}=\min
$$

where: $k$ is the number of gauging stations used in the optimisation process $(i=1,2,3, \ldots 9)$; $x$ is the known value of a descriptor (e.g. W50) or of another parameter (e.g. $t_{p}$ ); is the sought value of the descriptor (e.g. W50) or another parameter (e.g. $t_{p}$ ).

The optimisation process was carried out independently for the descriptors W50 and W75 and the skewness coefficient $s$, as well as the parameters describing the hydrograph: $n$ and $t_{p}$.

\section{RESULTS}

Table 3 gives the values of the descriptors (PCDs) obtained for the gauging stations in the catchment of the Raba River.

The Proszówki station was not considered in the construction of formulae describing the parametric flow hydrograph, because of the flood attenuation provided by the reservoir in Dobczyce.

Based on the determined PCDs, formulae were constructed to enable the computation of any parametric design hydrograph:

$$
\begin{gathered}
W 75=9.92 \frac{(1+L A S)^{1.54} G_{L E M O K^{1.14}}}{G S R^{1.68} S 1085^{0.55}(1+A D O)^{1.40} J E Z^{1.93}} \\
W 50=22.95 \frac{(1+L A S)^{0.70} G L E M O K^{0.79}}{G S R^{0.34} S 1085^{0.21}(1+A D O)^{0.27} J E Z^{2.92}} \\
S=0.14 \frac{G S R^{0.59}(1+L A S)^{0.18}}{G L E M O K^{0.91}}
\end{gathered}
$$

For Baptista's gamma density function, selected for description of the parametric design hydrograph, the following formulae were obtained:

$$
n=1.33 \frac{G S R^{2.53} S 1085^{0.70}(1+A D O)^{0.35}}{(1+L A S)^{3.24} G L E M O K^{3.75} J E Z^{1.81}}
$$

$t_{p}=25.45 \frac{1.0}{(1+L A S)^{0.92} \text { GLEMOK }^{0.60}(1+A D O)^{0.51} J E Z^{4.72}}$

Figure 5 shows the parametric flow hydrographs computed based on:

1. the hydrograph width at $50 \%$ (W50) and at $75 \%$

(W75) of peak flow and the skewness coefficient $s$, obtained from the nonparametric flow hydrograph obtained by Archer's method;

2. the hydrograph widths W50, W75 and the skewness coefficient $s$ computed from formulae (9), (10) and (11);

3. the parameters $n$ and $t_{p}$ of Baptista's gamma density function computed from formulae (12) and (13)

\section{ANALYSIS \\ AND DISCUSSION}

Formulae (9), (10) and (11) are basic equations for determining parametric flow hydrographs at any river cross-section. Their accuracy was assessed by comparing hydrographs determined from values of $W 50, W 75$, and $s$ from the nonparametric Archer hydrograph, with the hydrographs computed using formulae (9), (10) and (11) or formulae (12) and (13) for eight gauging stations on the Raba River. Table 4 gives the values of the relative error $(R E)$ for hydrographs computed at each gauging station for the two periods 1961-1990 (1990) and 1983-2012 (2012).

The relative error of hydrograph width was calculated from the following formula (Chai, Draxler 2014):

$$
R E_{p}=\frac{\left|W_{p}-\widehat{W_{p}}\right|}{W_{p}} 100 \%
$$

where: $R E_{p}$ is the relative error of hydrograph width $W_{p}, p=50 \%, p=75 \%$ or skewness co- 

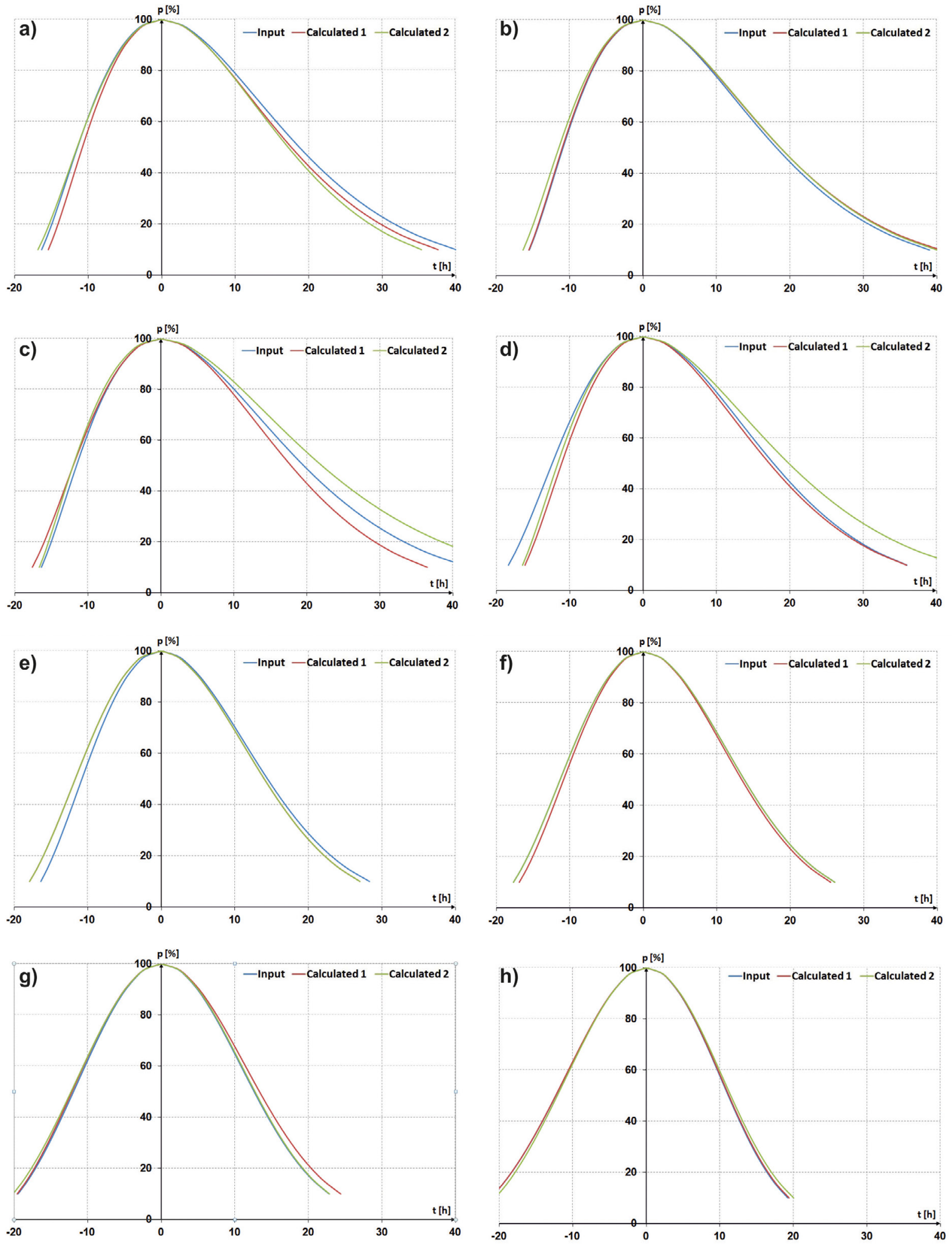

Fig. 5. Parametric hydrographs, where Input denotes the hydrograph obtained from the values $W 50, W 75$, and $s$ taken from the nonparametric Archer hydrograph; Calculated 1 denotes the hydrograph obtained from the values computed by formulae (9), (10) and (11); Calculated 2 denotes the hydrograph obtained from the values computed by formulae (12) and (13) - the Rabka gauging station on the Raba in 1990 (a) and 2012 (b); the Stróża gauging station on the Raba in 1990 (c) and 2012 (d); the Krzczonów gauging station on the Krzczonówka in 1990 (e) and 2012 (f); the Stradomka gauging station on the Stradomka in 1990 (g) and $2012(\mathrm{~h})$ 
efficient $s[\%] ; W_{p}$ is the hydrograph width at $p=50 \%, p=75 \%$ or skewness coefficient $s$ determined from the nonparametric design hydrograph $[\mathrm{h}]$; is the hydrograph width at $p=50 \%, p=75 \%$ determined from formulae (9), (10) and (11) [h].

According to the evaluation criteria, the qualities of the computed hydrograph widths W50, W75, and skewness coefficient $s$ for both periods may be classed as good and very good. To obtain a more reliable evaluation, further criteria were applied, based on comparison of the volumes and centres of gravity of the computed hydrographs with the hydrographs obtained from real data.

The volume of the hydrograph above the $p$-percent flow, for $p=50 \%$ and $p=75 \%$, was determined using the following definition (see Fig. 7):

$$
V_{p}=\sum_{i=1}^{N_{p}} V_{p, i}
$$

where: $V_{p}$ is the volume of the hydrograph above the $p$-percent flow, $p=30 \% ; N_{p}$ is the number of percent flows exceeding the $p$-percent flow: 16 for $p=30 \%$; $V_{p, i}$ is the partial volume of the hydrograph between successive $p$-percent flows.

The centre of gravity time coordinate was determined for the part of the hydrograph above the $p$-percent flow, $p=30 \%$ (see Fig. 7):

$$
r_{p}=\frac{\sum_{i}^{N p} V_{p, i} l_{i}}{\sum_{i}^{N p} V_{p, i}}
$$

where: $r_{p}$ is the time coordinate of the centre of gravity of the hydrograph above the $p$-percent flow, $p=30 \%[\mathrm{~h}] ; N_{p}$ is the number of percent flows exceeding the $p$-percent flow, i.e. 16 for $p=30 \% ; V_{p, i}$ is the partial volume of the hydrograph between successive $p$-percent flows [h]; $l_{i}$ is the time coordinate of the centre of gravity $r_{i}$ of the partial volume [h]; $r_{i}$ is the centre of gravity of the partial volume.

A comparison of volumes and centres of gravity of the hydrographs based on values computed using formulae (9), (10) and (11) with the hydrographs based on the values of $W 50$, W75, and $s$ found from the nonparametric Archer hydrograph is shown in Figure 8.

A comparison of the volumes and centres of gravity of the hydrographs based on values computed using formulae (12) and (13) with the hydrographs based on the values of W50, W75, and $s$ found from the nonparametric Archer hydrograph is shown in Figure 9.
Table 5. Quality measures for relative errors of hydrograph width Wp and skewness coefficient s

\begin{tabular}{|c|c|c|c|}
\hline quality & W50 & W75 & $s$ \\
\hline very good & $<10 \%$ & $<20 \%$ & $<10 \%$ \\
\hline good & $<10 \%, 15 \%)$ & $<20 \%, 40 \%)$ & $<10 \%, 15 \%)$ \\
\hline weak & $<15 \%, 20 \%)$ & $<40 \%, 60 \%)$ & $<15 \%, 20 \%)$ \\
\hline very weak & $\geq 20 \%$ & $\geq 60 \%$ & $\geq 20 \%$ \\
\hline
\end{tabular}

Table 6. Percentage contributions of quality measures for relative errors of hydrograph width W50, W75 and skewness coefficient $s$ for the periods 1961-1990 (1990) and 1983-2012 (2012)

\begin{tabular}{|c|c|c|c|c|c|c|}
\hline \multirow{2}{*}{ quality } & \multicolumn{2}{|c|}{ W50 } & \multicolumn{2}{c|}{ W75 } & \multicolumn{2}{c|}{$s$} \\
\cline { 2 - 7 } & 1990 & 2012 & 1990 & 2012 & 1990 & 2012 \\
\hline very good & $100 \%$ & $100 \%$ & $87.5 \%$ & $100 \%$ & $87.5 \%$ & $77.8 \%$ \\
\hline good & $0 \%$ & $0 \%$ & $12.5 \%$ & $0 \%$ & $12.5 \%$ & $22.2 \%$ \\
\hline weak & $0 \%$ & $0 \%$ & $0 \%$ & $0 \%$ & $0 \%$ & $0 \%$ \\
\hline very weak & $0 \%$ & $0 \%$ & $0 \%$ & $0 \%$ & $0 \%$ & $0 \%$ \\
\hline
\end{tabular}

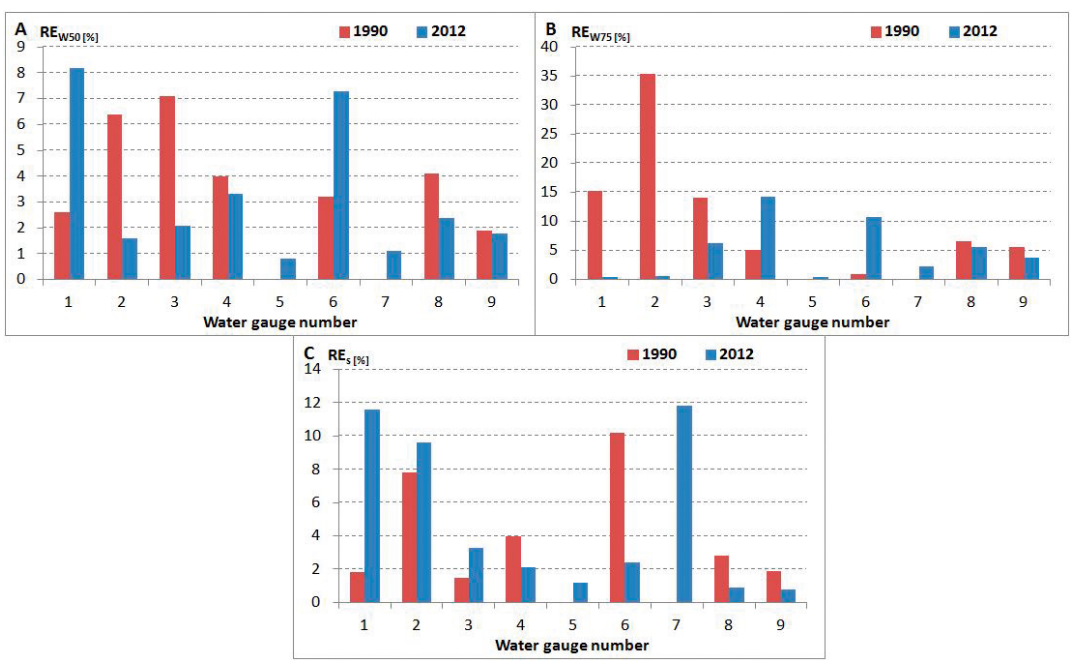

Fig. 6. Relative errors of hydrograph width Wp: A - for $p=50 \%, B-$ for $p=75 \%, C-$ for $s$, for the periods 1961-1990 (1990) and 1983-2012 (2012)

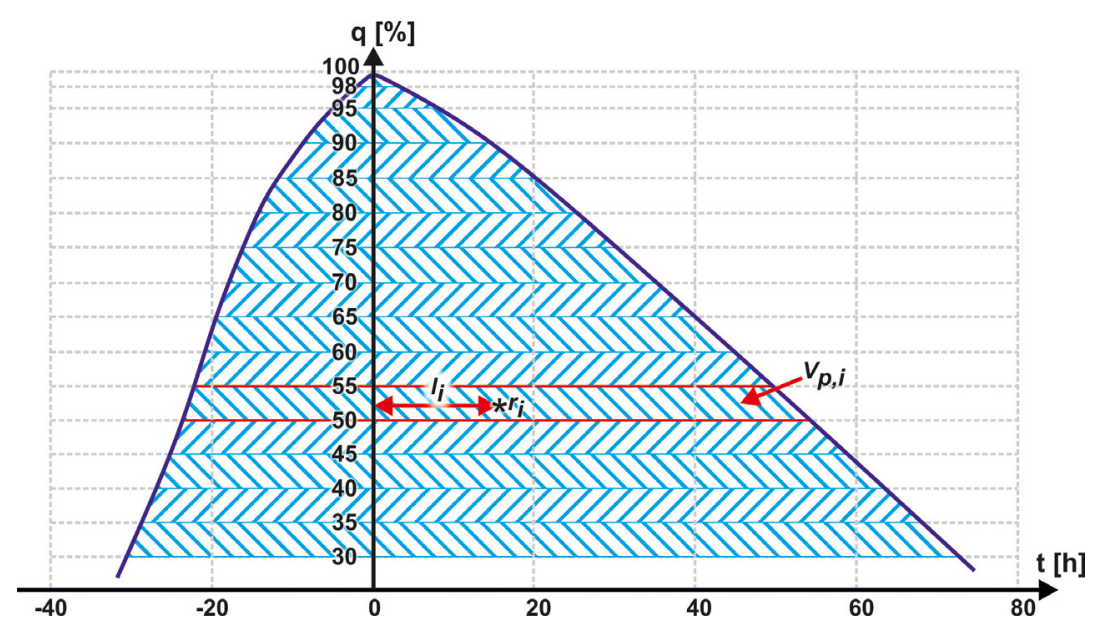

Fig. 7. Sketch for determining the partial volume of a hydrograph (trapezoid area) and the centre of gravity time coordinate used in equations 15 and 16 

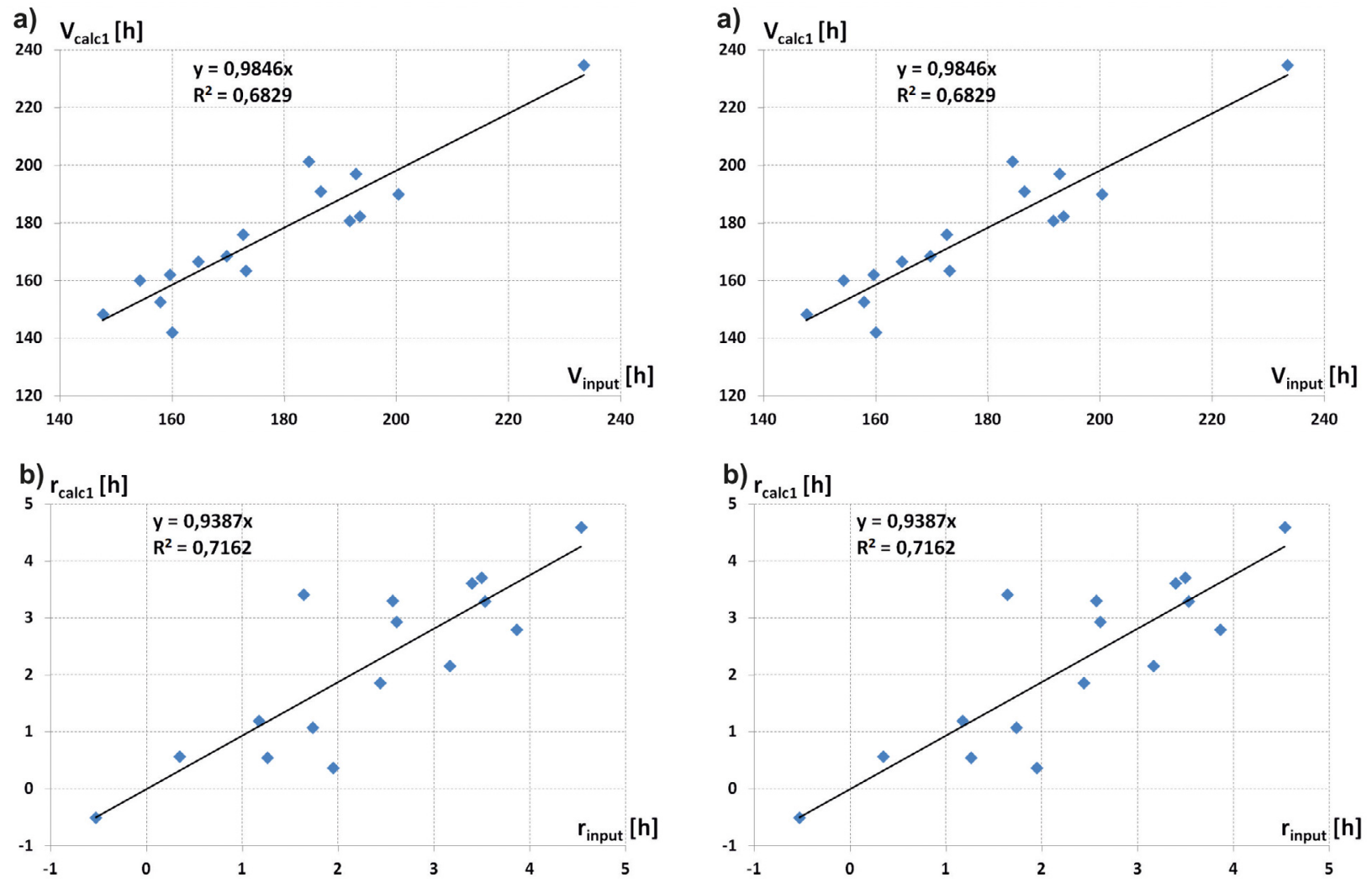

Fig. 8. Comparison of volumes (a) and centres of gravity (b) of parametric hydrographs computed using formulae (9), (10) and (11) with the volumes (a) and centres of gravity (b) of parametric hydrographs obtained using the values of $W 50, W 75$, and $s$ found from the nonparametric Archer hydrograph
Fig. 9. Comparison of volumes (a) and centres of gravity (b) of parametric hydrographs computed using formulae (12) and (13) with the volumes (a) and centres of gravity (b) of parametric hydrographs obtained using the values of $W 50, W 75$, and $s$ found from the nonparametric Archer hydrograph

\section{SUMMARY}

\section{AND CONCLUSIONS}

The proposed empirical formulae enabling the determination of parametric flow hydrographs confirm the possibility of implementing methods developed in Western European countries for the purposes of hydrology in Poland. The two presented groups of formulas (9), (10), (11) and (12), (13) represent independent methods for obtaining parametric flow hydrographs. The first group relates to computation of the values of hydrograph width at $p=50 \%, p=75 \%$ (W50, W75) and the skewness coefficient $s$, on the basis of which one may obtain a parametric hydrograph described by any function, e.g., the gamma density function, Baptista's gamma density function (Baptista 1990), the UPO-ERR gamma (O'Connor et al. 2014) or the Hayashi function (Hayashi et al. 1986). Thus, a parametric hydrograph can be determined in an optimum manner. In the case of the second solution the computed parameters are the wave shape $n$ and the time to peak $t_{p}$ for Baptista's gam- ma density function; this approach limits the freedom of choice of a function describing the parametric flow hydrograph.

The results for the catchment of the Raba River show that both solutions reflect the parametric flow hydrographs well. The agreement of the hydrographs in terms of volume and position of centre of gravity, as shown in Figures 8 and 9 , is satisfactory for both methods. The coefficient of determination $\left(R^{2}\right)$ for comparing the volumes of the hydrographs based on values of W50, W75, and $s$ from the nonparametric Archer hydrograph with those of the parametric hydrographs using formulae (9), (10) and (11) is 0.68 . When formulae (12) and (13) are used $R^{2}$ is 0.78 . For comparing the centres of gravity of the hydrographs based on the values of $W 50, W 75$, and $s$ from the nonparametric Archer hydrograph with those of the parametric hydrographs computed using formulae (9), (10) and (11), $R^{2}$ is 0.72 , and when formulae (12) and (13) are used $R^{2}$ is 0.78 . Comparing the position of centres of gravity checks that the volumes of the rising limb and the recession limb for the computed hydrograph agree with the hydrograph based on the values of W50, W75, and $s$ found from the nonparametric Archer hydrograph. The computed relative error for the values of hydrograph width at $p=50 \%, p=75 \%($ W50, W75) and the skewness coefficient $s$, along with their quality measures, confirm the possibility of applying the formulae for their determination at any river cross-section; this is an advantage of the proposed solutions. The quality of fit for W50 is extremely high; for W75 and $s$ it is slightly lower. It would therefore appear appropriate to verify whether the use of a value other than the hydrograph width at $p=75 \%$ might lead to a higher quality of fit of the hydrograph for that value.

The proposed solutions should be treated as verification of the possibility of implementing the methods applied in Western European countries for the purposes of hydrology in Poland. It is necessary to extend the field of study to other catchments and to verify how the quality of the results would be affected by using different physical catchment descriptors. 


\section{REFERENCES}

- Archer D., Foster M., Faulkner D., Mawdsley H., 2000, The synthesis of design flood hydrographs, [in:] Proceedings Flooding - Risks and Reactions, Conference by CIWEM and ICE, London, 45-57

- Baptista M., 1990, Contribution à l'étude de la propagation de crues en hydrologie. Hydrologie. Ecole Nationale des Ponts et Chaussees, available at https://pastel.archives-ouvertes.fr/pastel-00568722/document (data acces 06.08.2019)

- Baptista M., Michel C., 1990, Influence des caracteristiques hydrauliques des bies sur la propagation des pointes de crue, La Houille Blanche, 2, 141-148

- Bayliss A. C., 1999, Flood estimation book. Volume 5: Catchment descriptors, Institute of Hydrology, Wallingford, $130 \mathrm{pp}$.

- Chai T., Draxler R.R., 2014, Root mean square error (RMSE) or mean absolute error (MAE)? Arguments against avoiding RMSE in the literature, Geoscientific Model Development, 7 (3), 1247-1250, DOI: 10.5194/gmd-7-1247-2014

- Ciepielowski A., 1987, Statistical methods of determining typical winter and summer hydrographs for ungauged watersheds, [in:] Flood hydrology, V.P. Singh (ed.), Springer, Dordrecht, 117-124, DOI: 10.1007/978-94-0093957-8_10

- Ciepielowski A., 2001, Relationships between selected elements of the flood hydrographs in rivers, Journal of Water and Land Development, 5, 89-105

- Driessen P.M., Konijn N.T., 1992, Land-use systems analysis, Wageningen Agricultural University, Department of Soil Science \& Geology, Malang: INRES, $210 \mathrm{pp}$

- Gądek W., Środula A., 2014, The evaluation of the design flood hydrographs determined with the hydroproject method in the gauged catchments, Infrastruktura i Ekologia Terenów Wiejskich, 4, 1355-1366

- Gądek W., Tokarczyk T., 2015, Determining hypothetical floods in the Odra basin by means of the Cracow method and the volume formula, Infrastruktura i Ekologia Terenów Wiejskich, 4 (4), 1507-1519, DOI: 10.14597/infraeco.2015.4.4.109
- Gądek W., Tokarczyk T., Środula A., 2016, Estimation of parametric flood hydrograph determined by means of Strupczewski method in the Vistula and Odra catchments, Journal of Water and Land Development, 31, 43-51, DOI: 10.1515/jwld-2016-0035

- Gądek W., Baziak B., Tokarczyk T., 2017a, Nonparametric design hydrograph in the gauged cross sections of the Vistula and Odra basin, Meteorology Hydrology and Water Management, 5 (1), 53-61, DOI: 10.26491/mhwm/67911

- Gądek W., Baziak B., Tokarczyk T., 2017b, Strupczewski method for parametric design hydrographs in ungauged cross-sections, Archives of Hydro-Engineering and Environmental Mechanics, 64 (1), 49-67, DOI: 10.1515/ heem-2017-0004

- Hayashi T., Nagamine Y., Nishida A., 1986, A vibration model to describe the lactation curve of a dairy cow, Japanese Journal of Zootechnical Science, 57 (6), 471-478, DOI: 10.2508/ chikusan.57.471

- IMGW, 1980a, Podział hydrograficzny Polski. Część I: Zestawienia liczbowe, H. Czarnecka (ed.), IMGW, Warszwa

- IMGW, 1980b, Podział hydrograficzny Polski. Część II: Mapy, H. Czarnecka (ed.), IMGW, Warszawa

- IMGW, 1988a, Atlas hydrologiczny Polski. Tom I: Mapy, J. Stachy (ed.), IMGW, Warszawa

- IMGW, 1988b, Atlas hydrologiczny Polski. Tom II: Metoda opracowania, zestawienia liczbowe, J. Stachy (ed.), IMGW, Warszawa

- Mills P., 2009, Flood Studies Update Work-Package 5.3, Preparation of physical catchment descriptors, Report to OPW, available at https://opw.hydronet.com/ data/files/Work\%20Package\%205_3\%20 -\%20Final\%20Report(1).pdf (data access 06.08.2019)

- Mills P., Nicholson O., Reed D., 2014, Flood Studies Update: Technical Research Report. Volume IV: Physical catchment descriptors, available at https://opw.hydronet.com/data/ files/Technical\%20Research\%20Report\%20 -\%20Volume\%20IV\%20-\%20Physical\%20 Catchment\%20Descriptors.pdf (data access 06.08.2019)
- Mioduszewski W., 2012, Small water reservoirs - their function and construction, Journa of Water and Land Development, 17, 45-52, DOI: 10.2478/v10025-012-0006-z

- Mioduszewski W., 2014, Small (natural) water retention in rural areas, Journal of Water and Land Development, 20, 19-29, DOI: 10.2478/jwld-2014-0005

- Nash J.E., 1957, The form of the instantaneous unit hydrograph, [in:] General Assembly of Toronto, Vol. III, IASH Publications No 45, 114-121

- O’Connor K., Goswami M., 2009, Flood Studies Update: Work-Package WP-3.1 "Hydrograph width analysis". Final Report, available at https://opw.hydronet.com/data/files/ WP3_1\%20Hydrograph\%20Width\%20Analysis\%20-\%20Final\%20Report.pdf (data access 06.08.2019)

- O'Connor K., Goswami M., Faulkner D., 2014, Flood Studies Update: Technical Research Report. Volume III: Hydrograph analysis, available at https://opw.hydronet.com/data/files/ Technical\%20Research\%20Report\%20-\%20 Volume\%20III\%20-\%20Hydrograph\%20Analysis(1).pdf (data access 06.08.2019)

- Reed D.W., 2007, Flood Studies Update: Work-Package 5.4. PROPWET for Ireland: a dimensionless index of typical catchment wetness, available at https://opw.hydronet. com/data/files/Microsoft\%20Word\%20-\%20 Work\%20Package\%205_4\%20-\%20Final\%20 Report_1_.pdf (data access 06.08.2019)

- Reitz W., Kreps H., 1945, Näherungsverfahren zur Berechnung des erforderlichen Stauraumes für Zwecke des Hochwasserschutzes Deutsche, Wasserwirtschaft

- Strupczewski W., 1964, Równanie fali powodziowej, Wiadomości Służby Hydrologicznej i Meteorologicznej, 2 (57), 35-58

- Strupczewski W., Bogdanowicz E., Kochanek K., 2013, Discussion of "Synthetic design hydrographs based on distribution functions with finite support" by Francesco Serinaldi and Salvatore Grimaldi, Journal of Hydrologic Engineering, 18 (1), 121-126, DOI: 10.1061/ (ASCE)HE.1943-5584.0000538 